\title{
The ambiguity of Plato's Menexenus: A school manifesto
}

\section{Tito Storti}

\author{
(Alma Mater Studiorum - University of Bologna)
}

\begin{abstract}
No general agreement has yet been reached about the meaning and purpose of Plato's Menexenus. Two mutually exclusive readings have generally been given: Socrates' funeral oration could be either a parody and a satire of Athens' funeral speeches or an example of better, idealistic, maybe even philosophically grounded rhetoric. However, the problem does not only come from the dichotomy present in most scholars' works. It lies, instead, in the ambiguity of the text itself. This paper aims to clarify the serious implications that parody can have. Exemplarity and parody, irony and seriousness should not be considered as mutually exclusive because an imitation that seriously demonstrates how easy it is to write a good epitaph can be understood as a form of parody. In fact, Plato's Menexenus seems to be a school manifesto: it recalls Callicles' charges against the educational value of philosophical practices (Grg. 484c-485d). Therefore, it may be directed against Isocrates' conception of rhetoric as related to education and politics. The mention of the Peace of Antalcidas (245c) will then prove the topical and thus political character of this work.
\end{abstract}

\section{Keywords}

Menexenus; Gorgias; funeral speech; parody; rhetoric; school; Isocrates 


\section{Introduction}

No general agreement has yet been reached about the meaning and purpose of Plato's Menexenus. Despite differing opinions on the relationship between its framing dialogue and epitaph, the mimicry and criticism of funeral orations there contained has been generally accepted by modern scholars. Conversing with Menexenus, Socrates first criticizes harshly the institution of public funeral speech, but then offers an example of that kind of eulogy himself. This has led scholars to mutually exclusive interpretations differing on the crucial question regarding the presence of a serious tone in the epitaph or lack thereof.

According to some scholars, such as Pohlenz (1913), Méridier (1964) and Henderson (1975), the funeral speech has to be taken as an ironic extension of Socrates' critique, as an exemplification of the commonplaces widely used in democratic funeral speeches, as well as of the dangers and vacuity of rhetoric in general. A wide range of notions has been used to describe Menexenus' tendency: irony (Berndt 1881), parody (Dodds 1966), satire (Pohlenz 1913), raíyvıv (Ritter 1910), pastiche (Méridier 1964, Tsitsiridis 1998), persiflage. ${ }^{1}$

Wilamowitz (1920) has rather argued that Plato seriously meant the funeral speech as a demonstration of his superior rhetorical skills compared to contemporary rhetoricians, and that the preventive critique placed in front of it would be precisely due to the fact that its content is clothed in the form of such speeches. The idea has been developed by those who, like Pappas \& Zelcer (2015), understand Menexenus as a philosophical attempt to reform and reformulate that genre, and the appearance of Pericles' funeral speech in Thucydides' narrative could have well teased Plato. ${ }^{2}$ For many scholars Pericles seems in fact to be the main or even the only target of Menexenus. ${ }^{3}$ Some of them, such as Kahn (1963), detect a parenetic and protreptic tendency, while others, like Loewenclau (1961) and Tulli (2003), argue that Plato represented an 'Athens' Idea' according to his own beliefs.

Exemplarity and parody, irony and seriousness would therefore seem mutually exclusive. However, this dichotomy leads to a somewhat incoherent or uneven impression. ${ }^{4}$ On the one hand, those who stress Socrates' highly satirical account of the bewitching effect of rhetoric (234c-235c), then can hardly find any spoor of irony in the final conso-

1 Often several notions have been used together: see Wendland (1890: p. 180). According to Berndt (1881: p. 59), it is a "specimen ironiae mimicae", composed "artis Gorgieae imitatione".

2 The idea of a challenge that aims at improving and completing Pericles' epitaph is already proven in Pro-

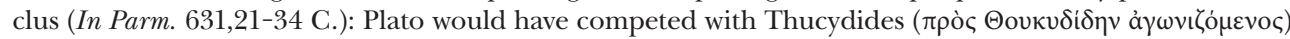

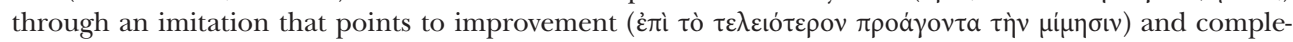

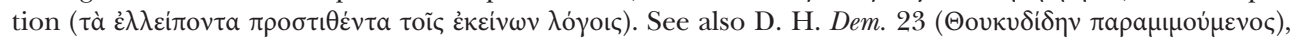
Hermog. Meth. 24, Anon. Proleg. Phil. Plat. (22,61-63 W.).

3 See for instance Labriola (1980).

4 Many felt an unbearable shift in tone between dialogue and funeral speech: see Ritter (1910: p. 487), Pohlenz (1913: p. 303), Lattanzi (1953: p. 303). Even between praise and consolation a shift to a graver register has been assumed, often without a proper explanation: cf. Kennedy (1963: p. 159), Henderson (1975: p. 45), Salkever (1993: p. 140). 
lation (246a-249c) and are therefore obliged to undermine its value. ${ }^{5}$ On the other hand, those who pay attention just to the funeral speech have to disregard Socrates' outspokenly ironic praise of rhetoricians. ${ }^{6}$ Since a lack of parody or satire in the prosopopoeia of the fallen (246d-248d) is widely accepted, how could it be possible to imagine a work written half as a parody and half not? ${ }^{7}$ And considering that the content of the funeral speech is clearly suited in the style of Gorgias, it might be hard to understand why Plato embedded with such a derogatory dialogue a speech that he meant seriously.

\section{The framing dialogue}

A closer analysis of the framing dialogue reveals a tight connection to Gorgias and may answer the question whether Socrates' epitaph should be taken seriously or not. Socrates' charges can be summarized as follows: 1) The public funeral democratic character and the 'honourable death'topos undo any difference between citizens, because they are praised for the qualities they partake of, but also for what they actually don't partake of

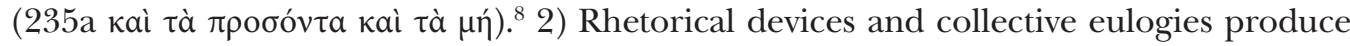
an ephemeral enchantment of empty grandeur. 3) Despite the conventional difficulty of facta dictis exaequare, the task is easy and does not require particular skill, for the speakers make use of speeches prepared in advance and because, even if improvisation is needed, the eulogy will always find a welcoming audience (235d). ${ }^{9}$

Socrates denounces a discrepancy between the alleged difficulty in finding words appropriate to the deeds and the actual ease in carrying out this task: "if a man contends in front of the very people whom he praises, it is no big deal to seem a fine speaker" (235d, cf. 236a).

Socrates implies that rhetoricians only flatter their public, and this is the general

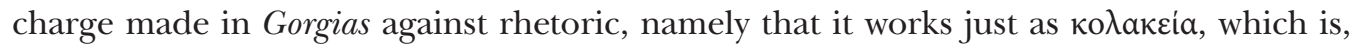

5 See Méridier (1964: p. 72) and Clavaud (1980: p. 247).

6 See especially Pappas \& Zelcer (2015: pp. 5, 82).

7 This point is rightly stressed by Tsitsiridis (1998: p. 82).

8 Pericles (Th. II 42,3) makes a conscious use of that topos for community purposes. The expression kai tà

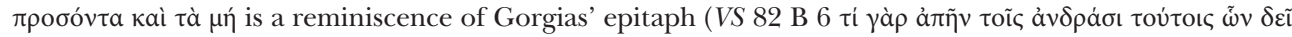

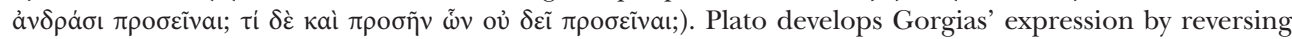
its meaning: if the fallen do not lack anything that must be owned nor possess anything that must not be

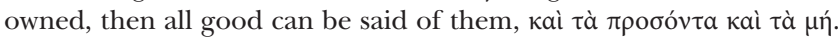

9 The speaker's inadequacy to equal the deeds with his own words is a widely used topos, it works as captatio benevolentiae, and takes the form of a recusatio, cf. Th. II 35,1f., Lys. 2,1, D. 60,1, Hyp. 6,2, Isoc. 11,14, 74, 82. In Menexenus' prologue (236d-e) the elaborated antithesis of $\lambda$ ó $\gamma \circ \varsigma_{-\varepsilon}^{-\varepsilon} \rho \gamma o v$ highly alludes to the one of Pericles (see Kahn 1963: p. 222, Tsitsiridis 1998: p. 180), but the meaning is subverted: the $\mu v \eta \dot{\eta} \mu$ and

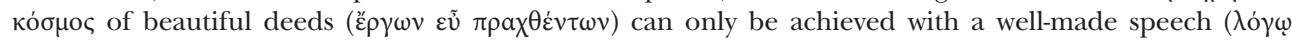
$\kappa a \lambda \tilde{\omega} \varsigma \dot{\rho} \eta \dot{\varepsilon} v \tau \iota)$. This contrived confidence seems to satirize the common device of undervaluing speakers' own abilities and is coherent with Socrates' critique: an eloquent, confident speaker who praises his own citizens requires no excuse, for the task is actually easy. Plato therefore does not show "how much better

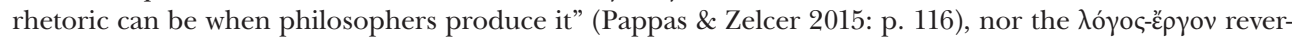
sal implies that "the philosopher is free from having to pretend that logos is empty" (id.: p. 121). 


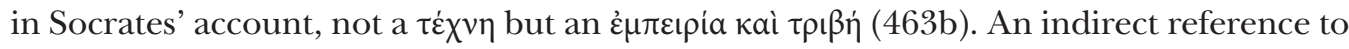

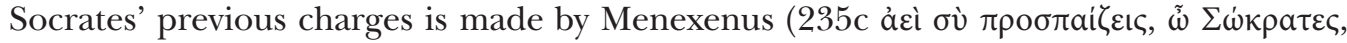

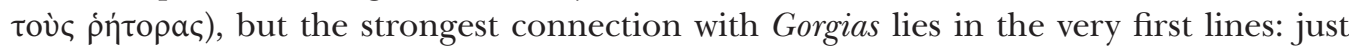

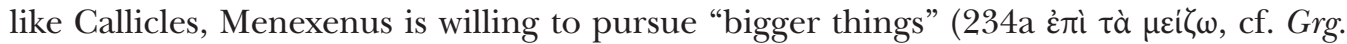
$484 c$ ) - i.e. a career in politics - because he deems to have already completed his educa-

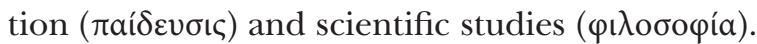

A sign of Menexenus' tendency lies where Socrates says that he fears Mexenenus will laugh him to scorn if he will see an elder man like him playing as a child (236c à $\lambda \lambda^{\prime}$ ' ' $\sigma \omega \varsigma$

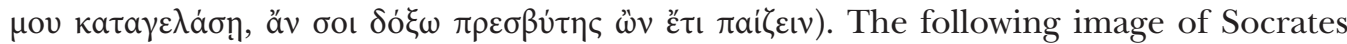
dancing while taking off his coat may be comical, but above all suggests that $\pi a i \zeta \varepsilon v v$ refers to an alien behaviour of Socrates, or an insignificant task without any value, namely the acting of the funeral oration. This is a plain reference to Callicles' charge against Socrates and the practice of philosophy (Grg. 485a): in Callicles' opinion, "it is

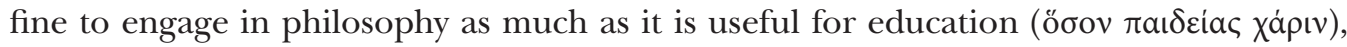
and for a young man it is not vile to follow it; but if a man already in his late years (ク̋ $\delta \eta$

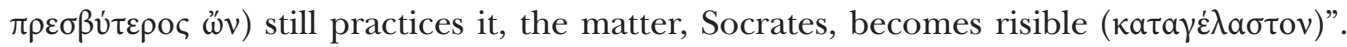
Callicles argues that if men do not engage in public life and still practice philosophy,

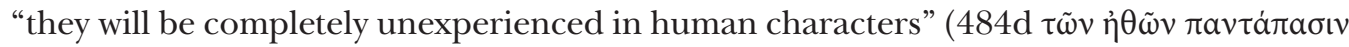
ä́rııроı).

It should therefore be clear that Callicles' allegations refer to a discussion on education. He argues that the practice of philosophy would be well-suited for a young man, but if one wants to pursue a career in politics, he needs to be taught in rhetoric, for it prepares to practical life. The young Menexenus is eager to ä $\rho \chi \varepsilon ı v ~(234 a)$, and therefore

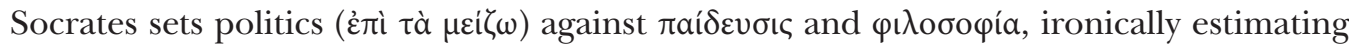
the first as "bigger" than the latter two.

It seems now useful to consider Menexenus' addressees: does it address a wide audience, i.e. the whole citizenship (as argued by those who consider it a political pamphlet), or an absolutely restricted public which can grasp every allusion, or rather those young people who wish to perfect their education, as the title itself suggests? Plato's Menexenus seems related to a genre which depicts young aristocrats who are too confident in their skills and too eager for äpxeıv. In fact, we know of other works devoted to Menexenus, ${ }^{10}$ and a conversation between Socrates and a young, bold Glaucon (Xen. Mem. III 6) fits quite well the current discussion: pressed by Socrates, Glaucon is forced to admit his total lack of preparation in terms of armies, finances, and charisma. Socrates, after having diverted the young man from dedicating himself too soon to a political career, advises

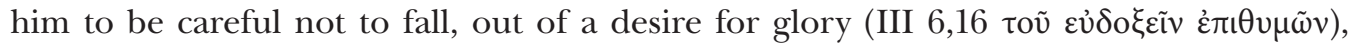
into its opposite.

The cultural panorama provided by Plato's Menexenus involves eminent political leaders (Archinus, Dion, Pericles), teachers of dubious and undoubted reputation (Aspasia,

10 A Menexenus was written by Glaucon, Plato's elder brother (cf. D. L. II 124) and Antisthenes (SSR V/A

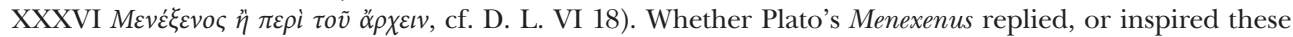
works, is impossible to say. Certainly later is Aristotle's Menexenus (D. L. V 22). Also Philon Megarius wrote a Menexenus (SSR II/F VI ap. Clem. Al. Strom. IV 19,121,5). 
Connus, Antiphon, Lamprus), while the addressee is Menexenus, young heir of an illustrious Athenian family (234b). The young age of Menexenus, his inclinations towards

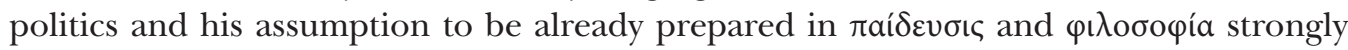
suggest to consider education, rhetoric teachers, politics and command as themes and targets of Plato's Menexenus.

The thematic coherence with Gorgias and the clear disregard of oratory practice can hardly support a philosophical interpretation. It seems therefore unlikely to assume that $\pi \alpha i \zeta \varepsilon ı v$ refers to Socratic irony, as Kahn (1963: p. 226) and Tsitsiridis (1998: pp. 66-67) do. The opening dialogue does not contain any evidence of the will to reform funeral orations. Besides being short and ornamental, the closing conversation appears aporetic, i.e. it does not seem to have any further meaning to be drawn from it. As Oppenheimer (1933: p. 72) pointed out, Menexenus' evaluation of the speech is essentially "bewundernd und anerkennend", and does not contain Plato's real belief, as Wilamowitz (1920: p. 141) expected. The final section does not aim at belittling the worth of Socrates' speech, as one may assume from Socrates' opening critique. It just proves that Socrates has spoken in a way convenient to the occasion, just as Agathon did (Smp. 198a $\pi \rho \varepsilon \pi o ́ v \tau \omega \varsigma)$.

That Menexenus does not claim the need for philosopher-rulers, as instead Coventry

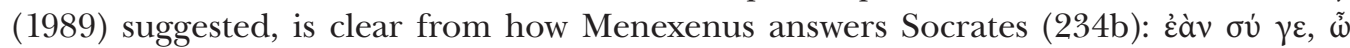

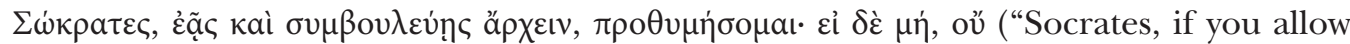
and advise me to govern, I will govern; if not, I will not"). "Die plumpe Ehrerbietigkeit" (Schleiermacher 1861: p. 261) that Menexenus would show towards Socrates has led some to believe that Menexenus is spurious, or at least that the young man is heavily mocked (Nannini 2014: p. 265). More than deference, one could speak of indifference. The superiority of philosophical education is implicit from the very beginning, when Socrates asks the young man if he really believes to be at the end of his education. It is implicit, not discussed: the theoretical bases of criticism are to be found in Gorgias, to which Menexenus might serve as an ironic, explanatory counterpoint. ${ }^{11}$

However, an overall evaluation of Menexenus' tendency cannot be drawn without a proper analysis of the speech itself, since it seems to be lacking in evident parodic techniques, such as distortion, inversion and amplification.

\section{The funeral oration}

The wide, florid, and introductory section on autochthony (237b-238b) works as pivot for the entire speech and arises again in those very places suspected of (perhaps bitter)

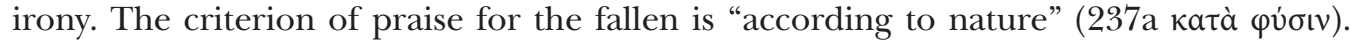
The relevance of this parameter has been often disregarded, though it widely departs from the common arguments of praise, namely the virtue and courage of the fallen,

11 "A playful appendix", according to Dodds (1966: p. 24). 
their attachment to the city, Athens' generosity and moral superiority, etc. ${ }^{12}$ One could infer Socrates' seriousness from the importance that Plato recognised to founding myths (Criti. 109b-d, Ti. 23e-24c, Sph. 247c, Plt. 269b-271c), and in fact Menexenus seems to recall the "noble lie" ( $R .414 \mathrm{~b}-415 \mathrm{e})$, where equality of birth is merged with a merit-based hierarchy. Even though the autochthony theme and the assimilation of Attica to a mother are widely used commonplaces, ${ }^{13}$ the brotherhood and consequent equality among

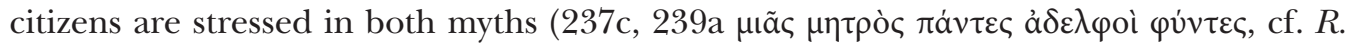

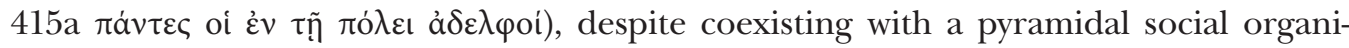
sation. In Menexenus' praise of Athenian constitution, which is surprisingly defined as ápıбтократía, the goodness of the constitutional form would be due to equality of birth (238e $\dot{\eta} \dot{\varepsilon} \xi$ loov $\gamma \varepsilon \dot{\varepsilon} \varepsilon \sigma ı \varsigma)$, and the natural factor of birth equality would lead to legal equal-

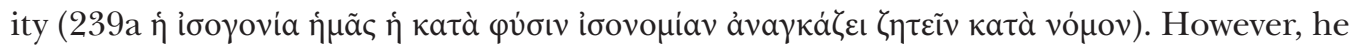

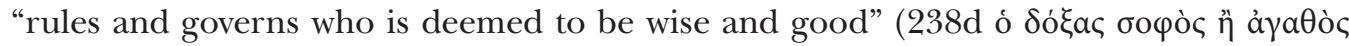

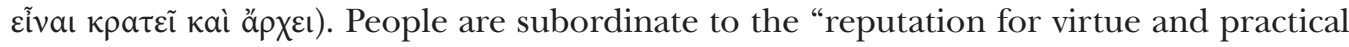

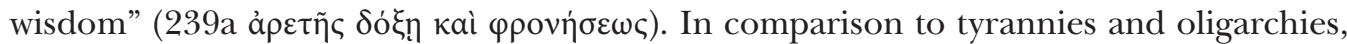

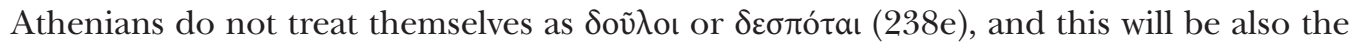
behaviour of kallipolis' people (R. 463a).

These comparisons seem to be sufficient enough to rule out the possibility of a mere imitation, i.e. a school exercise, and may show how much relevant for Plato was a mythical foundation. They also may support the view that Plato set here some of his own beliefs. However, an extended praise of Athenian noble origins may well have been the normal habit in funeral orations, since Pericles' extremely brief reference to the topos and his praeteritio on Athenian deeds (Th. II 36) serve to highlight his departure from more traditional speeches. Furthermore, a deep philosophical meaning seems unlikely. The insistent imitation of the forensic habit of seeking argumentative evidence plays

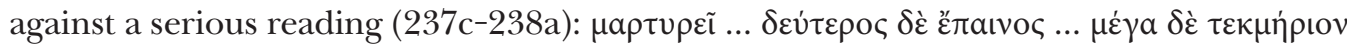

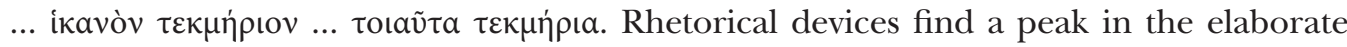

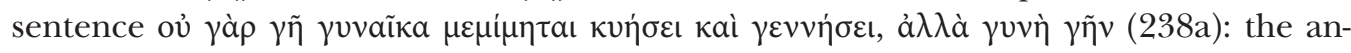

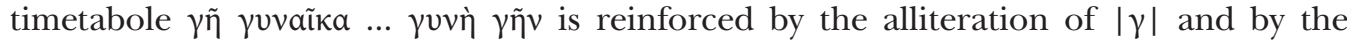

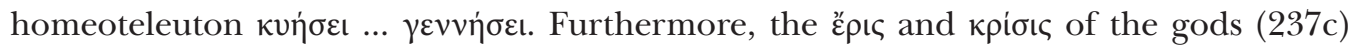
are cited as proof of divine love for Attica, but they are denied in Criti. 109b. The divine contention for the possession of Attica belongs in fact to the encomia-repertoire, ${ }^{14}$ and therefore proves the lack of a truly platonic thought.

Moreover, the resumption of autochthony motifs elsewhere in Menexenus should cast a shadow about Plato's alleged seriousness. They occur not only in the praise of Athenian constitution, where Pericles' funeral oration is clearly hinted. In fact, the moderation that Athenians would have proven after the fall of the Thirty Tyrants would be due to $\dot{\eta}$

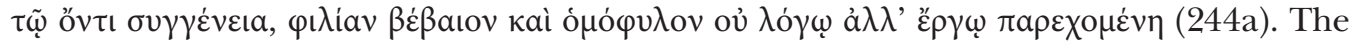
$\sigma v \gamma \gamma \varepsilon \dot{v \varepsilon}$ เa which would have fostered a mild and moderate reconciliation sounds at least

12 See Ziolkowski (1981: p. 134).

13 Cf. e.g. Hdt. VII 161,3, Ar. V. 1076, Eur. Ion 589f., Th. I 2,5, II 36,1, Lys. 2,17-19, Isoc. 11,24f., 21,124, 17,49, D. 60,4. As for the comparison of Attica to a mother, see Isoc. 11,25, 21,90, 16,108, Plat. R. 470d. 
ironic, if not profoundly bitter. It is true that after the fall of the Thirty the outgoing party actually behaved moderately in battle,$^{15}$ and that the slogan of the winners was appeasement and reconciliation. ${ }^{16}$ But the reconciliation with those of Eleusis was conducted far from $\mu \varepsilon \tau \rho i \omega \varsigma$ (244a), it was a traitorous slaughter. ${ }^{17}$ It is unlikely that the $\sigma v \gamma \gamma \varepsilon \dot{v \varepsilon l a-}$ theme, and therefore the firm character of $\varphi$ i $\lambda$ ia, depends on mere conventionality, or sincere idealisation: a little further on, where the firm refusal of Athens to the peace of Antalcidas (a peace that Athens actually agreed to) is praised, the motif of Athens' noble freedom returns, which is healthy, firm, and naturally hostile to Barbarians (245c tó $\gamma \varepsilon$

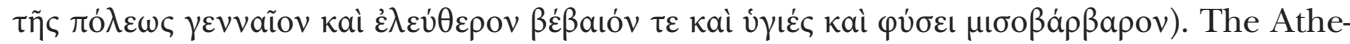
nian nature would be so purely Hellenic (245d) that Athens alone would not have agreed to take the oath. It is not a question of replacing the truth with a nobler, albeit insincere image of Athens that can serve as an inspiring model, as Kahn (1963: p. 225) suggested. Plato seems to reuse sarcastically the well-known topos of Athenians' autochthony: the Athenian nature would be so pure and its character so firmly $\varphi \dot{v} \sigma \varepsilon \iota \mu$ Athens has paradoxically accepted to sign a peace completely unbalanced towards the interests of the Persians!

The countless readings given to the politeia section (238b-239a) reveal once more Men-

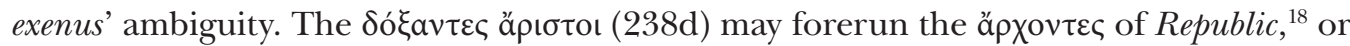
reveal not so much Plato's real judgment about the Athenian constitution, but, instead, his own political aspiration directed to the citizenship. ${ }^{19}$ Conversely, the "Durcheinanderwirblung der staatsrechtlichen Begriffe" ${ }^{20}$ would prove Plato's satire. However, while the upheaval of actual power relations has been understood just as "Provokation", ${ }^{21}$ the enigmatic, unexpected and embarrassing definition of "an aristocracy with popular

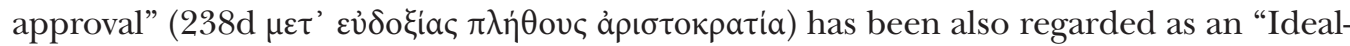
isierung der attischen Verfassung". ${ }^{22}$

The overall meaning of the politeia's depiction seems to be, however, a fine and sly lengthening of Pericles' praise of Athenian constitution. Both Pericles and Plato deal

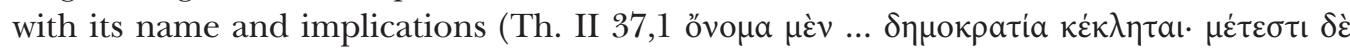

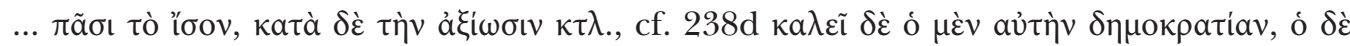

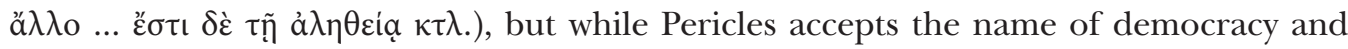
clarifies some correctives that distinguish it from ochlocracy, Plato directly rejects that

15 Cf. Xen. Hell. II 4,19.

16 See Cleocritus' speech in Xen. Hell. II 4,20-22.

17 Cf. Xen. Hell. II 4,43.

18 Wilamowitz (1920: p. 132).

19 Kahn (1963: p. 226).

20 Pohlenz (1913: p. 245).

21 Heitsch (2009: p. 233).

22 Tsitsiridis (1998: p. 227). The exact meaning of $\varepsilon \dot{\delta} \delta o \xi i \alpha$ is unclear. Its general and most common meaning is 'good repute', 'honour', cf. Tsitsiridis (1998: p. 224): "[eine Aristokratie] mit dem guten Ruf der Menge”. Relying on Men. 98b-99b, some scholars translate it with 'good judgement', 'correct opinion', cf. Labriola (1980: p. 210): "una aristocrazia fondata sul buon giudizio della massa". The majority of scholars understands it as 'approval', cf. Kahn (1963: p. 222): "an aristocracy with the approval of the multitude". I hope to clarify the meaning of this word and its implications in another contribution. 
name and calls it an aristocracy, i.e. the rule of the best. If Pericles, against the partisan meaning, entrusts $\delta \eta \mu$ кратia with the value of 'government of the whole people', Plato sets $\pi \lambda \tilde{\eta} \theta$ o against $\delta \eta \mu$ кратia, which therefore means 'the government of the poor'. Pericles welcomes the word democracy, but strives to show that geometric, not arithmetic,

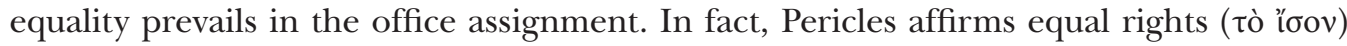

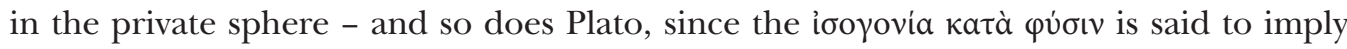

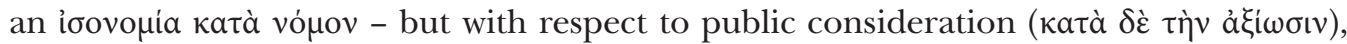

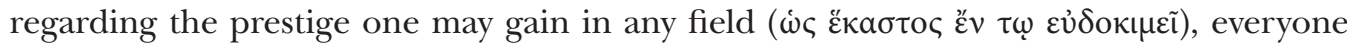

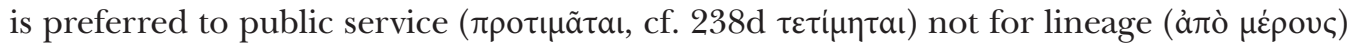
more than for merit ( $\left.\dot{\alpha} \pi^{\prime} \dot{\alpha} \rho \varepsilon \tau \tilde{\eta} \varsigma\right)$.

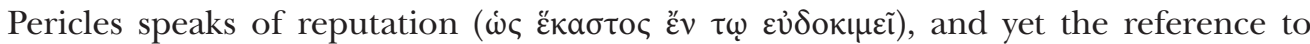
reputation (i.e. appearance/opinion) ceases to exist when he states that everyone is preferred according to a meritocratic principle (å $\pi^{\prime}$ ả $\left.\rho \varepsilon \tau \tilde{\eta} \varsigma\right)$. In other words, Pericles im-

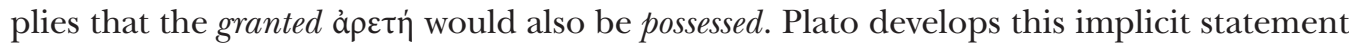

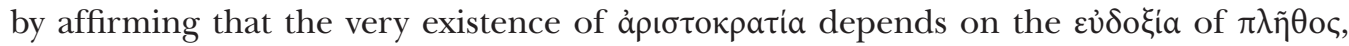

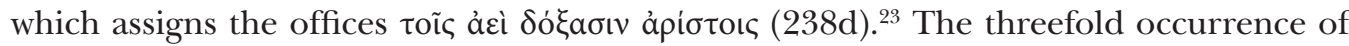
ठокє̃̃ (238d [2x], 239a) highlights how arbitrary is the merit-based principle in Pericles' speech. If the people really had a correct opinion, Plato seems to say, an ápıбтократía could indeed be realized.

The "preference" (

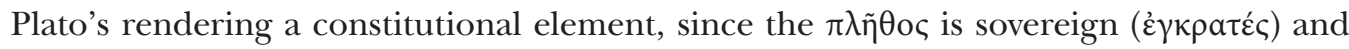
therefore can assign power and political offices to whomever it may deem to be the best. Therefore, the merit-based principle praised by Pericles turns into Plato's $\delta$ ó $\alpha v \tau \varepsilon \varsigma$

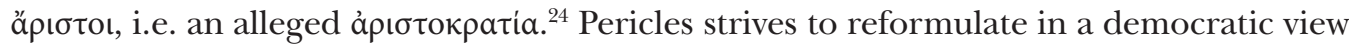
the aristocratic, merit-based principle, while he hides public consideration - i.e. appearance - behind it. Pericles' merit-based system seems to be innate in the Athenian $\varphi v$ oıs, and therefore Plato transformed this natural peculiarity into a constitution based on law.

Menexenus' politeia is nothing more than the natural extension of Pericles' implicit message. By making explicit these implicit words, Plato made evident the mystifying character of Pericles' praise. By adhering to the genre conventions, Plato reused Periclean vocabulary to affirm its seclusion from reality. This confirms the duplicity that structures Plato's Menexenus: respect for tradition and traditional themes on the one hand, allusive criticism $e$ contrario on the other.

Both serious and parodic readings recognise the tendentiousness of the historical account (239a-246a), since it may well be interpreted in both ways. According to Wilamow-

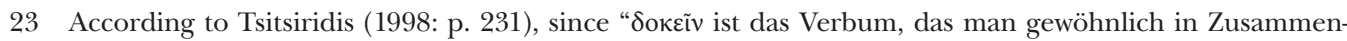
hang mit einer Wahl oder einer Entscheidung des Volkes gebraucht", the verb would not really contain a polemic allusion to the distinction between being and appearing. The effort shown in removing any form

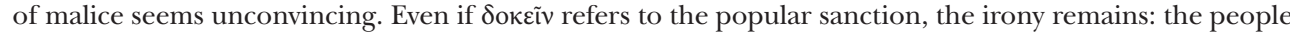
have agreed who are the best, that is, they have concurred who they hold to be the best.

24 The statement lengthens Thucydides' judgement of Pericles' influence: "what was a democracy by name,

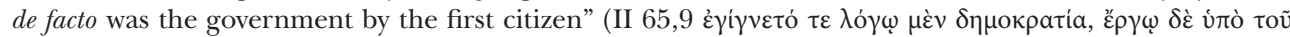

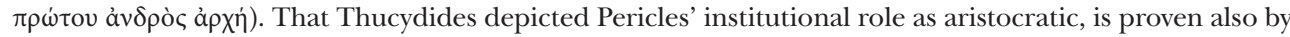

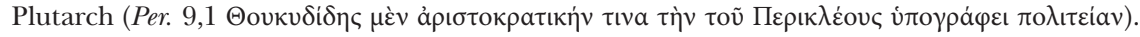


itz (1920: p. 135), Plato took his stand on Athens' politics, giving to it "Richtungslinien". According to others, the section has to be taken as a celebration of the ideal behaviour that Athens should have had in foreign policies, ${ }^{25}$ perhaps turned into criticism to spur the city to be worthy of such a nobler version of itself. ${ }^{26}$ On the contrary, this section may just exemplify the habits of official rhetoric, which distorts history through exaggerations, subversions and deliberate omissions. ${ }^{27}$

However, both readings seem inappropriate for at least two reasons. It has often been wrongly assumed that misstatements, exaggerations, and silences derive from precise choices, i.e. there is a certain meaning to be drawn from them. Conversely, a satirical tendency has been detected thanks to modern historical knowledge. In other words, the historical account has been read through the eyes of a modern historian. It has been rightly stated that a fair amount of misstatements may be unintentional, and, thefore, they can just show that Menexenus is a funeral oration, and not an historical research. In fact, it is possible to judge historical discrepancies just on the basis of the sources known at that time, and one has to be careful not to overlook the peculiarities of this genre, since it conveys Athens' official, therefore positive version of its history. ${ }^{28}$ From the mere presence of inaccuracies nothing can be drawn, beside the fact that they mimic widely used themes.

If Plato adopts a well-established practice and does really mimic rhetorical embellishments of history, however, it is unlikely to assume a serious aim for such distortions. However, many felt that Plato amplifies and deliberately exaggerates the inaccuracies and revisions of Athenian eulogies. ${ }^{29}$ In fact, Menexenus seems to contain statements too gross and too evident to be dismissed just as imitation. Therefore, a proper evaluation of the chosen events, of the way they are presented, and of the reasons for which they are recalled is essential.

There are surely some arguments which may support a serious reading. Since the mythical deeds are mentioned just in the form of praeteritio (239b), a satire stricto sensu can be ruled out here. In fact, they belong to the most traditional themes of Athenian encomia and might be surely enlarged and enriched, as Lysias' funeral speech and Isocrates' Panegyricus show. ${ }^{30}$ Moreover, the particular emphasis with which is exalted the value of Marathon (240c-e) - a field battle, and not a naval one - is consistent with Plato's judgment expressed much later in $L g$. 707c. An aristocrat like Plato could only blame the naval, i.e. democratic, policies of Athens. Another consistency may be found in the panhellenic character of Socrates' historical account. Athens' generosity towards other Greeks is based on the principle that against people of the same blood one fights

25 Scholl (1959), Loewenclau (1961), Tulli (2003).

26 Kahn (1963).

27 Among the others, Berndt (1881), Wendland (1890), Pohlenz (1913), Taylor (1960), Méridier (1964), Moggi (1968), Henderson (1975).

28 These points are rightly stressed by Kahn (1963: p. 225) and Tsitsiridis (1998: pp. 74-76).

29 See for instance Henderson (1975: p. 39) and Trivigno (2009: p. 38).

30 Cf. Arist. $R h$. II 1396a 12-14, Lys. 2,4-6, 7-10, 11-16, Isoc. 11,54-65, 68-70, D. 60,8 and Pohlenz (1913: p. 275). 


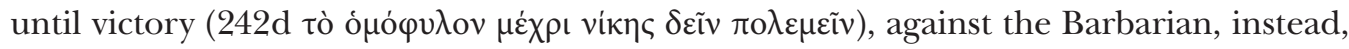
until destruction. Athens took on countless conflicts "in its own interest and that of all who speak the same language” (242a). This is consistent with Plato's distinction between

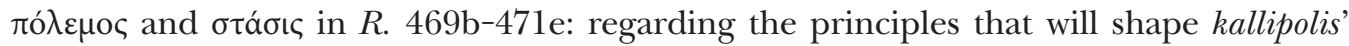
art of warfare, Plato sharply distinguishes between $\pi$ ó $\lambda \varepsilon \mu \circ \varsigma$, which pertains to the alien

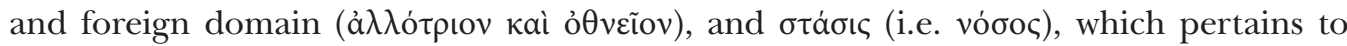

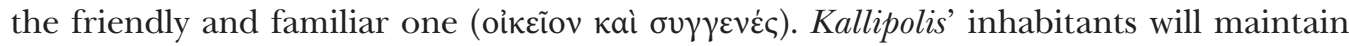
a reconciliation perspective with their enemies and the punishment will not turn into

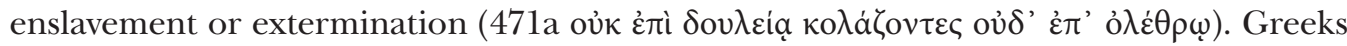
must not fight other Greeks in the same way as they do towards Barbarians, since the Greeks are by nature their enemies. Moreover, Plato's originality has to be noted. The account of Persian growth and the Eretria-episode (239d-240c), which recurs also in $L g$. $698 \mathrm{c}-\mathrm{e}$, do not seem to belong to the epitaph-repertoire.

However, it has not been sufficiently noticed that, in the Persian growth's section, the $\delta$ ov $\lambda \varepsilon i a$ theme recurs insistently as a consequence of the enlargement of Persians' $\dot{\varepsilon} \lambda \varepsilon v \theta \varepsilon \rho i \dot{\alpha}$ and therefore à $\rho \chi \eta^{\prime} \cdot{ }^{31}$ It has been rightly stated that Menexenus' historical account seems to contain no mention of Athenian à $\rho \chi \eta \dot{~(w h i c h ~ i s, ~ i n s t e a d, ~ p r o u d l y ~ p r a i s e d ~}$ by Lysias) ${ }^{32}$ probably because Plato could have had nothing but words of reproach. But if not to Athens, to which city are the words about Darius' kingdom suited, "with ships [he] controlled the sea and the islands, so that he believed he had no antagonist of equal value"? ${ }^{33}$ Does it not resonate here Pericles' proud claim that Athens forced $\pi \tilde{a} \sigma a v \mu \varepsilon \dot{\varepsilon} v$

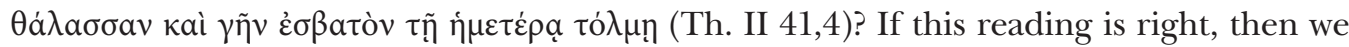
have to conclude that an allusion to Athenian 'imperialism' is present, though referred to the Persian kingdom, as well as a devaluation of an à $\rho \chi \eta \dot{~ t h a t ~ g e n e r a t e s ~ e n s l a v e m e n t . ~}$ In fact, the closer the account comes to the disgraceful peace of Antalcidas, the more the $\delta$ ou $\lambda$ cia theme recurs. ${ }^{34}$

Moreover, some statements about the period 404-386 are too bold to be dismissed as

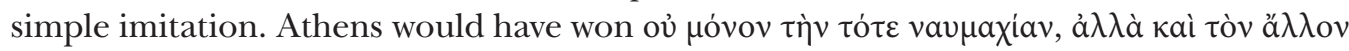
$\pi$ ó $\lambda \varepsilon \mu$ ov (243d) - i.e. the Peloponnesian War - because "we have been defeated by our

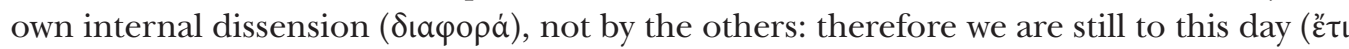

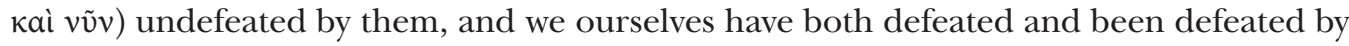
ourselves". Thucydides too links the cause of Athenian defeat to internal disagreements

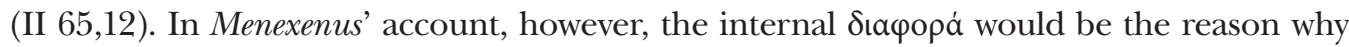
Athens cannot be regarded as defeated. It would be Athens itself that caused its own end,

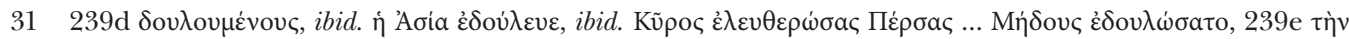

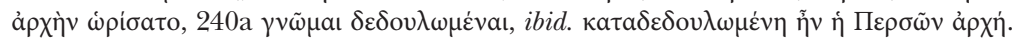

32 Lys. 2,47, 55, cf. Isoc. 11,106 and Kahn (1963: p. 225).

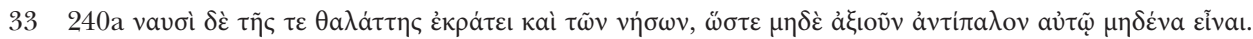

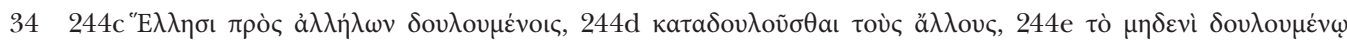

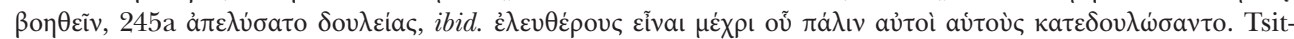
siridis (1998: p. 79), although he refuses the satirical reading of Pohlenz, admits the presence of "eine

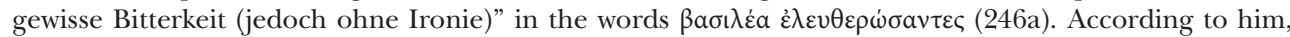
all the Athenians would be praised, regardless of where (or for whom) they have fought. However, the 'regardless of' itself is coherent with Socrates' critique and therefore plays in favour of a bitter irony. 
which would depend on no one else but itself. Tsitsiridis (1998: p. 327) finds the reasoning "sophistisch". It would be equally sophistic to recall the distinction between $\pi$ ó $\lambda \varepsilon \mu o \varsigma$ and

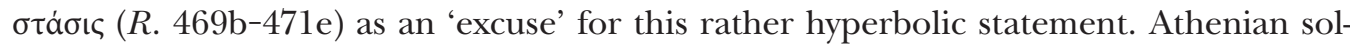
itude at war is a commonplace which underlines Athenian courage and credits towards the other Greeks, ${ }^{35}$ and Plato seems to force this topos to absurdity.

The topical character of Plato's Menexenus is proved not only by these bold statements, but also by their connection to the present situation. Athens would have won the Peloponnesian War and therefore would have been "still undefeated to this day". Athenian aristocracy is praised because of its continuity, since it "still exists in present times". ${ }^{36}$ Even those who regard the praise of politeia as idealisation recognise that these emphatic references to the present play against a sincere depiction of Plato's beliefs or aspirations. ${ }^{37}$ Plato could have well avoided such striking references, and yet he did not do so. The historical account therefore proves how much topical the Menexenus is.

The final exhortation and consolation $(246 a-249 c)$ have been often regarded as the most 'truly Platonic' section of the whole speech. Dionysius (Dem. 30), whose judgement on the incipit is rather severe, reports favourably an entire passage (246c-248e). Even though some scholars recognised the traditional character of moral prescriptions and therefore excluded a purely philosophical content, ${ }^{38}$ there seems to be general agreement in considering this section truly worthy of Plato. Since exhortation and consolation might fit a philosophical treatment of virtue and pain, then Plato would have had more freedom and familiarity in dealing with such topics in his own fashion. ${ }^{39}$ If Méridier (1964: p. 72 $)^{40}$ had to undermine their value in accordance with his reductive reading, a shift to a graver tone has been often assumed without a proper explanation, namely without considering that «a shift in tone is just what one would expect when moving from celebration and praise to consolation and exhortation». ${ }^{41}$

35 See Ziolkowski (1981: p. 135).

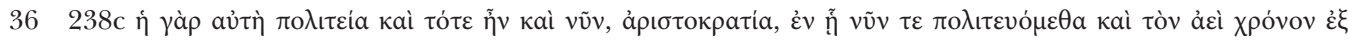

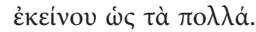

37 See Tsitsiridis (1998: p. 87): "Diese direkte Bezugnahme auf die Gegenwart, die ins Auge springt, hätte der Autor vermeiden können, indem er einen milderen oder allgemeineren Ausdruck benutzt hätte".

38 Cf. Blass (1874: p. 435), Berndt (1881: p. 55), Pohlenz (1913: p. 292), Wilamowitz (1920: p. 137).

39 See Wendland (1890: p. 192), Ritter (1910: p. 496), Pohlenz (1913: p. 292), Kahn (1963: p. 229), Monoson (1998: p. 502), Eucken (2003: p. 54).

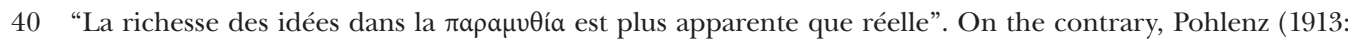
p. 293) sees even here a "satirische Beziehung" and detects in the closing section a critical allusion to city's shortcomings towards the families affected by the loss. References to the awareness of special care

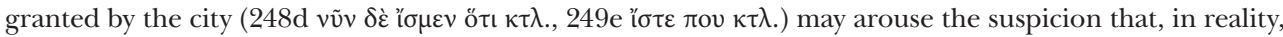
Plato would denounce a lack of the city. In an apparently autonomous way Huby (1957: p. 113) came to the same conclusion, and the idea was also welcomed by Kahn (1963: p. 234 n. 28) and Trivigno (2009: p. 44). It is however unlikely to regard Mеnеxenus as a 'leading article' of Plato on specific laws, at least because that concern would make the nephew of Critias, so to speak, a 'socialist'.

41 Trivigno (2009: p. 41). 
The speaker addresses the living with words ${ }^{42}$ that recall Socrates' solemn oath, ${ }^{43}$ and, at least from Wilamowitz (1920: p. 137) on, this was taken as a proof of Plato's seri-

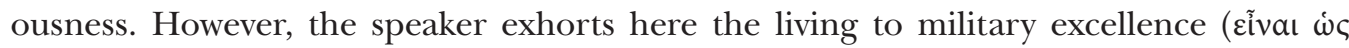

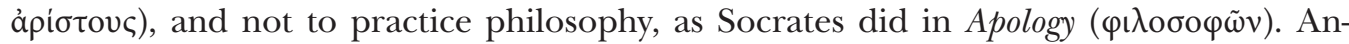
other consistency with Plato's conception of virtue has been found in the consolation of the parents, where the need to contain affections and grief is stressed several times. ${ }^{44}$ According to the speaker, whoever makes all that bring about happiness depend on himself, and whose life does not depend on the others, he has the best preparation for

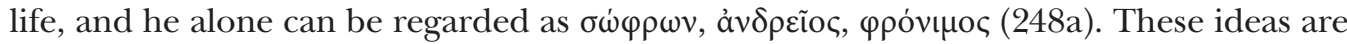

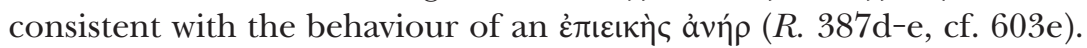

However, the overall argument is rather traditional, if not properly archaic. The pivot of parents' consolation is the Delphic maxim $\mu \eta \delta \dot{\varepsilon} v$ ä $\gamma \alpha v$ (247e), which is also the core of a famous piece of Archilocus (fr. 13 W. ${ }^{2}$ ). In comparison with other classical funeral orations, Plato made here a larger use of highly ancient and archaic conceptions. No wonder that Plato could share such traditional thoughts.

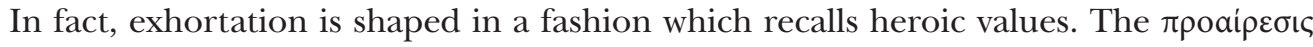
of the fallen is based on the shame that would have come down to their lineage if they had not carried out their duty (246d), ${ }^{45}$ while Pericles' development of such theme (Th. II 42,2f.) highlights a constant interaction, a strong bond between Athens and its citizens. They are tied in a mutual reliance represented by the "contribution" (ह̌pavoৎ, 43,1) given freely and without any further interest by the fallen to the city. Menexenus shows, on the contrary, that Athens plays no role in the choice of the fallen. And in this silence, perhaps, lies the meaning of this section.

Lineage permeates the ethical code of archaic honour, for the individual existence is recognised only as a part of a family organism, whose origins are lost in myth and whose future ideally must not come to end. For this reason, fame is not so much a personal possession as a common $\theta$ q $\sigma$ avpós (247b). Not to spend ancestors' noble store, but rather to increase and deliver it to the descendants is the duty which the children must accomplish for their fallen fathers. ${ }^{46}$ In other words, the ápetri of the ancestors (i.e. genos) constitutes the benchmark according to which the ápet⿳่ of the family members is judged. A metaphorical contest based on virtue reflects one of the leading ideas of archaic thought and is well set out in the solemn speech between Odysseus and his son (Od. XXIV 506-515). Telemachus must not disgrace his genos showing cowardice, and Laertes calls the con-

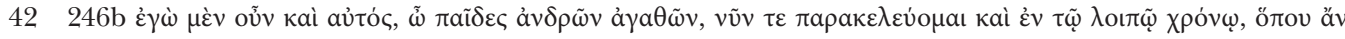

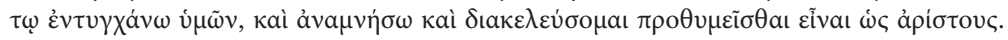

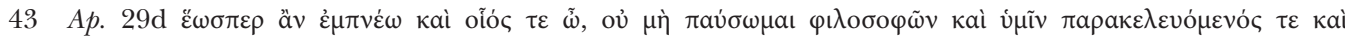

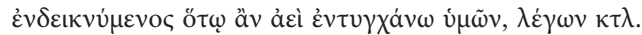

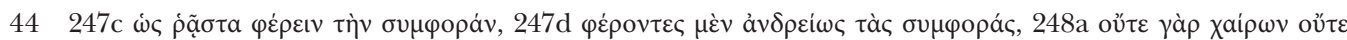

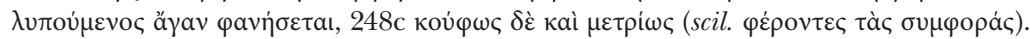

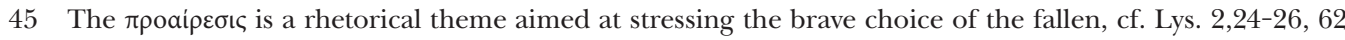
and D. 60,26-28.

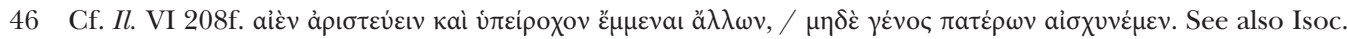
4,29 . 


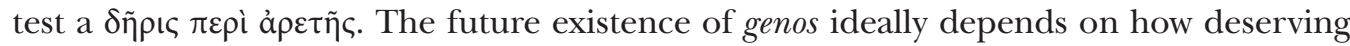
Telemachus will prove to his father.

Pericles too makes use of a metaphorical contest $(45,1$ ó $\rho \tilde{\omega} \mu \dot{\varepsilon} \gamma a v$ tòv ả $\gamma \tilde{\omega} v a)$. Howev-

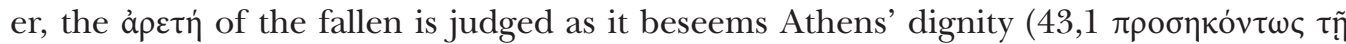
$\pi$ ó $\lambda \varepsilon \imath)$. Menexenus shows a rather different ethic, which is based on lineage conceptions. The merit of the living is no longer assigned in accordance with public consideration and common utility, but rather with an afterlife perspective (246d, 247c, 248c). Therefore, no further speculations on the philosophical meaning of this section are needed. It seems that Plato selected the very core of heroic ethic in order to give to his funeral speech all the dignity it deserved.

To summarise, serious readings are right in denying that Plato offered a mere imitation of funeral speeches, because Plato's purposes might be underestimated. Moreover, the many parallels might confirm this view, but inferring from them some positive content seems wrong. From such similarities it is possible to infer only that Plato shared certain ideas, such as the importance of a founding myth, the need for greater cohesion between Greek poleis, the heroic and archaic ethic of virtue as honour and courage, and the control of excessive grief. A philosophical or pedagogical intent has been often sought - or even applied a priori - by softening Socrates' ironic behaviour, and, therefore, by 'naturalising' Menexenus in Plato's philosophical system. However, this "injection massive de conceptions philosophiques ou de préjugés historiques" ${ }^{47}$ is not based on the text, but in comparison only with other dialogues. A positive content, on the other hand, might be justified by the opening of Plato's Academy, which was possibly established a few years earlier, ${ }^{48}$ and a serious reading seems to be shared by some ancient authors.

The ironic reading rightly leads to carefully consider the implicit relations with the genre and its conventions. It points out the significant number of rhetorical devices and therefore the imitation of Gorgias' style. It stresses the mockery of rhetorical practices in the opening dialogue. It suggests being cautious in identifying parallels too easy to assert a positive content. In fact, the propositio and dispositio of the prologue, as well as many other transitions, sound quite scholastic. ${ }^{49}$ Moreover, in the framing dialogue there is no sign that Socrates' speech is free from the same charges he points out. If Socrates' speech had a positive content, the framing dialogue would seem out of place. A moral use of history might fit the ancient past, but some direct references to the present prevent such reading.

To overcome this dichotomy, it is necessary to understand Menexenus' ambiguous character. The odd effect that it causes is due to the way it is constructed. If one reads Menexenus as a whole, it is difficult that not even a shadow of doubt arises about the presence of irony. However, taken out of its context, the funeral oration seems to be a brilliant piece of oratory. The speech is designed to look like a true one, and, therefore, it is hard to trace evident exaggerations, accumulations, amplifications or semantic

47 Clavaud (1980: p. 64).

48 See Kennedy (1963: p. 160) and Tsitsiridis (1998: p. 84).

49 See Wendland (1890: p. 183), Méridier (1964: p. 66), Tsitsiridis (1998: p. 85). 
reversals, which are typical mechanisms of parody. An overall evaluation must take in account that the speech is both independent from and subject to the framing dialogue.

\section{A school manifesto}

It remains now to consider background and purpose of Plato's Menexenus. The thematic coherence with Gorgias leads to consider not so much rhetoric in itself, but rather the educational value of rhetoric as core discussion of this dialogue. In fact, it seems to illustrate certain practices of schoolteachers and may be understood as a mockery of Isocrates' conception of rhetoric as related to education and politics. The young age of Menexenus, his willingness to leave education for a career in politics, and his apparent disregard for further scientific studies refer, indeed, to the quarrel between Plato and Isocrates about the contents of a proper education.

Just like Callicles, who, according to Socrates, received a sound education ( $\mathrm{Grg}$. 487b

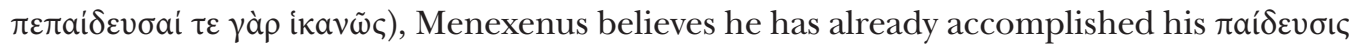

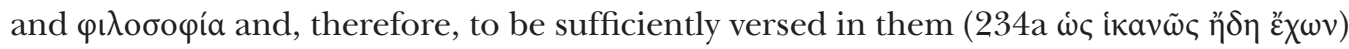
to pursue a career in politics. In Callicles' opinion, the practice of philosophy deals with

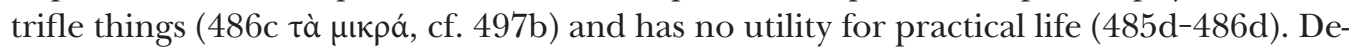
spite considering philosophy as suitable for a young man, given that it proves his liberal mind and may foreshadow a brilliant future, Callicles sees as risible the fact that an elderly man may still practice philosophy. Similarly, Callicles has the same feeling towards

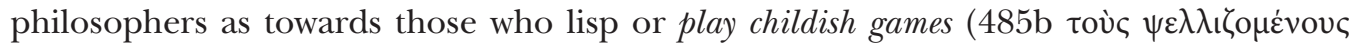

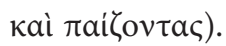

Callicles' position recalls to some extent Isocrates' educational programme, which the latter asserted in several works right after the foundation of his school. According to Isocrates, "to make likely conjectures about useful things is way better than having exact knowledge about the useless" $(9,5)$. Young men, however, may well be forgiven for deepening such useless knowledge, since they are naturally inclined towards extraordinary and marvellous things $(9,7)$. In Helena Isocrates states how hard it is, conversely, to compose speeches of general import and adequate form to fit any given situation, just as practicing seriousness is far more demanding than levity, i.e. playing like a child (9,11 tò

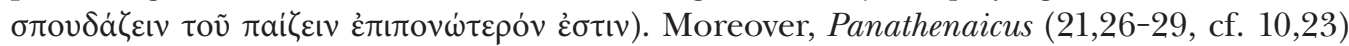
contains statements even closer to Callicles' charges. Isocrates states that, even though elder people should find subjects like geometry, astronomy, and the so-called eristic intolerable, these may well please young men. At any rate, such disciplines prevent them from other harmful things and therefore can be regarded as useful and fitting occupations. However, those who practice them in their old age seem not only to fail to use this knowledge properly, but also to be less cultivated than their own pupils. Isocrates, instead, aims at discussing graver and nobler things, namely the affairs of Hellas, kings, and states (21,11). As early as in Panegyricus (11,1-14), Isocrates asserted his own way of teaching and composing: according to him, stylistic refinement of a speech must go hand in hand with the relevance of the subject, it must enhance speaker's skills, and be 
useful for the audience, whose lives are improved by this kind of speeches $(11,189)$. In fact, Isocrates aims at speaking about great and noble things, which address people's well-being and the common good $(19,276)$.

In light of these statements, Socrates' contrived fear of being scoffed by Menexenus,

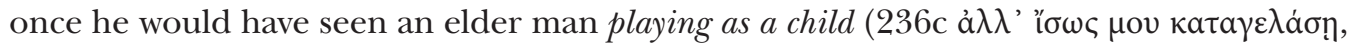

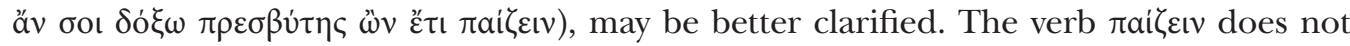
only refer to an alien behaviour of Socrates, or to an insignificant task without any value. It is Socrates' counterpoint towards Callicles' allegations, which partially recall Isocrates' conception of education. In Menexenus Socrates undertakes the task of demonstrating how easily a good funeral oration can be composed. Hence, he seems to assert that not so much the practice of scientific studies, but rather the composition of a brilliant speech is a childish task, for it does not require any particular skill, nor does it involve any risk of failure.

Menexenus witnesses a quarrel between opponent schools and diverging conceptions of education, and this is clarified by certain features of the framing dialogue. The schooling setting of Menexenus, its mimicry of school practices, and the presence of technical terminology related to the 4 th century schooling debate have been often underestimated.

Socrates praises the eloquence of those rhetoricians who do not praise randomly

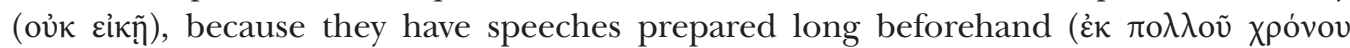
$\lambda$ ójo $\pi \alpha \rho \varepsilon \sigma \kappa \varepsilon v a \sigma \mu \varepsilon \dot{v o l}$ ), and embellish the speech with the most beautiful words (235a

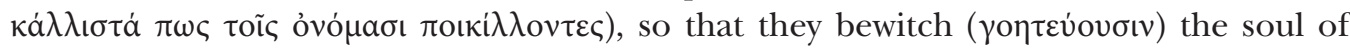

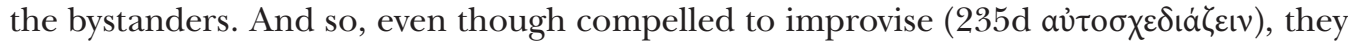
do not encounter any difficulty, and not only because they have ready-made speeches: if a speaker contends before the very people whom he praises, Socrates states, it is no big

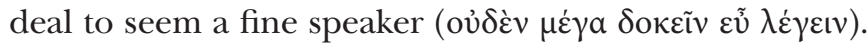

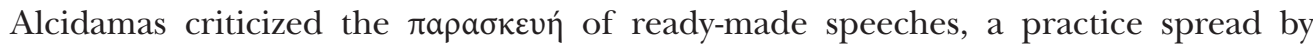

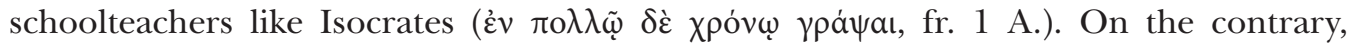
Isocrates aims at choosing the fitting elements for each subject, in order to arrange them properly and to embellish appropriately the whole speech, speaking therefore with flow-

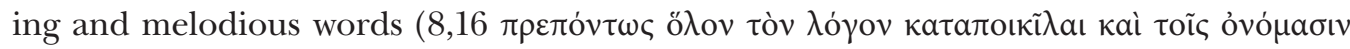

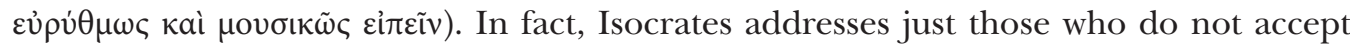

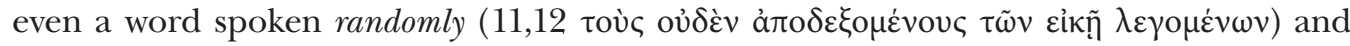
criticizes speakers' habit of flattering their hearers by making excuses about their lack of preparation, the difficulty of improvising or finding words appropriate to the greatness of their theme $(11,13)$.

Hence, Plato's Menexenus contains some technical words which refer to a current dis-

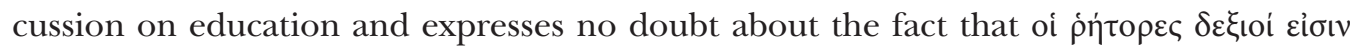
(235c). It rather recognises and demonstrates the bewitching effect of speeches made by school masters, and therefore questions the educational value of their art.

Moreover, the short sketch of Socrates' apprenticeship under Aspasia contains seeds of a technical vocabulary. Socrates heard Aspasia recite a funeral speech in its entirety

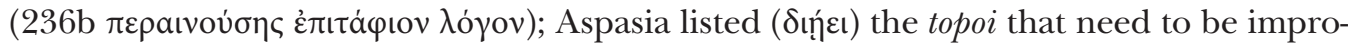

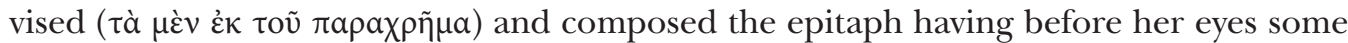




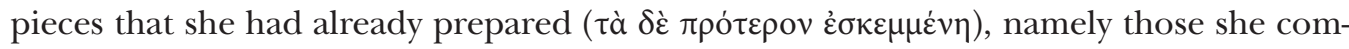
posed for Pericles; Aspasia glued together ( $\sigma \cup \gamma \kappa о \lambda \lambda \tilde{\omega} \sigma \alpha)$ the improvised parts with such residues and then forced Socrates to memorise them. It is very likely that the expression $\tau \grave{a} \delta \dot{\varepsilon} \pi \rho o ́ \tau \varepsilon \rho o v$, apart from being an allusion to Pericles' speech, refers to the topoi that a funeral oration always needs to contain. The verb $\sigma \kappa \varepsilon \dot{\varepsilon} \tau o \mu a$ recalls a preliminary phase of study, while $\sigma v v \tau i \theta \eta \mu$ indicates the composition and $\pi \varepsilon \rho a i v \omega$ the presentation. Moreover, $\sigma v \gamma \gamma \mathrm{\gamma} \lambda \lambda \dot{\alpha} \omega$ is linked with untruthful speeches already in Aristophanes $(\psi \varepsilon v \delta \tilde{\omega} v$

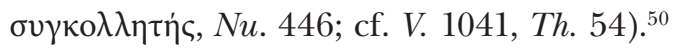

Aspasia is praised for her excellence in rhetoric, for her exceptional pupil, and teaching method. The figure of Aspasia, as mistress of Pericles and inflexible $\delta\llcorner\delta a ́ \sigma \kappa a \lambda o \varsigma$ §ंторıкп̃ (236a) of Socrates, personifies above all the school rhetorician, the teacher of rhetoric. The caricatural traits of Aspasia mock certain school practices, such as the habit of learning speeches by heart: Socrates remembers perfectly Aspasia's speech also because, as he reveals to Menexenus, he risked to receive the blows of his teacher every time he forgot a passage (236c).

It must be borne in mind that the portrayal of Aspasia as an outstanding and unforgiving teacher of the most prominent Athenians is taken from Old Comedy, and this plays in favour of a parodic reading. ${ }^{51}$ Moreover, Aspasia derives her traits from the homonymous works of Aeschines and Antisthenes, and this is supported by the literary and schooling activity run by Aspasia in Menexenus. ${ }^{52}$ Aspasia and Pericles are literary figures that carry an educational and, in this respect, political meaning. Aspasia writes brilliant speeches and seduces bystanders' mind. However, she offers nothing that pertains to

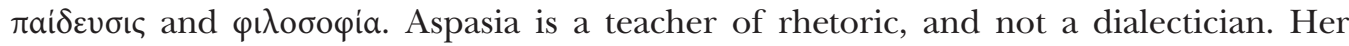
charm and skill bewitch, instead of educating. Aspasia is a skilled speaker and therefore very dangerous.

50 For these references I am indebted with Labriola (2010). The value of $\pi \varepsilon \rho \iota \lambda \varepsilon^{\prime} \mu \mu \alpha \tau \alpha$ should not be overestimated with Nannini (2014: p. 253) and Pappas \& Zelcer (2015: p. 106). Their value is not so much in the content, but rather in their nature of residues, artfully reused and glued together with parts improvised

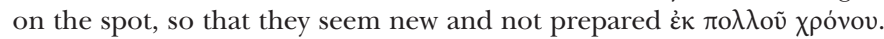

51 Both the scholium (schol. Plat. Mx. 235e) and Plutarch (Per. 24) recall the names with which Old Comedy

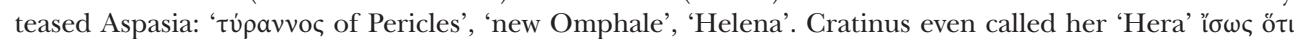

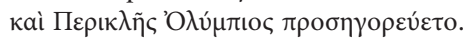

52 As for Aeschines' Aspasia (SSR VI/A 59-72), there is a general agreement in believing that it was centred on Aspasia's pedagogical activity. It dealt with the Socratic theme of é $\rho \omega \varsigma$ and that of $\beta \varepsilon \lambda \tau i$ iov $\gamma^{\prime} \gamma v \varepsilon \sigma \theta a$, i.e.

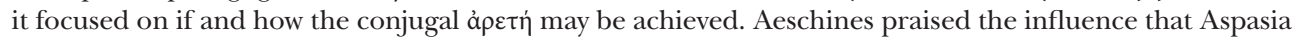
had on Pericles' eloquence and upheld the positive value of Gorgias' rhetorical style. Since Aeschines adopted Gorgias' style in his works (cf. D. L. II 60), his defence of Aspasia has been understood as an attempt to defend himself. As to Antisthenes' Aspasia (SSR V/A 142-144), there is too little evidence to trace structure and content of the dialogue. However, it is possible to infer an essentially negative evaluation of the sensual influence that Aspasia had on Pericles. 


\section{Conclusion}

Plato's Menexenus must be read in the light of a double competition: one involving the Academy and Isocrates' school for educational primacy and one between Plato and other Socratics within the Academy. Characters' meaning and polemical implications must be understood through Plato's constant controversy towards other interpretations of Socrates (Aeschines, Antisthenes) and Athenian schools. Aeschines offers a positive version of Aspasia, almost a female counterpart of Socrates, expert in $\delta\llcorner\alpha \lambda \varepsilon ́ \gamma \varepsilon \sigma \theta a ı$ and marital issues. Conversely, Antisthenes points out the dangers of Aspasia's eros by negatively judging the influence she exerted on Pericles. Plato's Aspasia conveys firstly the differing interpretations given by Aeschines and Antisthenes, and, secondly, a debate on teaching and eloquence.

In this respect, a central theme of Menexenus is the educational role of rhetoric. In fact, it replies to Callicles' allegations found in Gorgias against the educational value of philosophy as Plato saw it, namely a constant scientific research. After the theoretical criticism of rhetoric launched in Gorgias, it is likely that Plato considered appealing the attempt to demonstrate to speakers, namely politicians, how easily a funeral speech can be written, and indeed a good one.

The epitaph does not simply confirm and extend the charges made by Socrates in the opening dialogue. It shows how little effort is required for composing a brilliant literary product. The speech is neither more nor less than a good example of this genre. Plato has seriously played on one of the most patriotic genres at Athens, and the appearance of Pericles' funeral oration in Thucydides' work may well have encouraged Plato to take this path.

A discussion about rhetoric could not be separated from that about the very politics which spread and fostered that kind of eloquence, and in fact Menexenus' mise en scène recalls some prominent figures of 5th century Athens. It is necessary, therefore, to keep in mind the topical character of this dialogue.

Tsitsiridis (1998: p. 81) denies the presence of satire because both recognisable distortions and clear criticism would be lacking, as well as the necessary unmasking and exposure on which the protreptic intention of a satire is based. However, it is very likely that all these impressions were evident to contemporary readers right after the peace of Antalcidas. A recognisable distortion of the events seems clear in the account of the years 404-386. Consequently, a clear criticism had to be recognizable due to the historical consequences of the peace, and not only due to Socrates' words in the framing dialogue. An unmasking of eulogies' mystifications becomes clearer, moreover, the more attention is paid to the original reworking of Pericles' praise of Athenian constitution. Plato made explicit the implicit traits of Pericles' message, and this can well be understood as exposure. A discrepancy between Athenian imaginary and reality may no longer be comprehensible to us, but it had to be evident to the ancient reader.

In this respect, the serious implications that parody can have may be better clarified. Exemplarity and parody, irony and seriousness should not be considered as mutually exclusive, for a protreptic tendency seems present, if we regard Menexenus as a school 
manifesto. Plato did not entrust it with a positive content, but rather with a negative one. In other words, Plato wanted to remove any educational value from the political meaning of discourse as Isocrates intended it. By doing that, Plato affirmed the educational primacy of his school, not by proposing a positive content, but rather by belittling the political and educational conception of rhetoric professed by Isocrates.

\section{Bibliography}

Berndt, T. (1881). De ironia Menexeni Platonici. Münster: Academica Coppenrathiana.

Blass, F. (1874). Die attische Beredsamkeit (Vol. II). Leipzig: Teubner.

Clavaud, R. (1980). Le Ménexène de Platon et la rhétorique de son temps. Paris: Les Belles Lettres.

Coventry, L. (1989). Philosophy and rhetoric in the Menexenus. Journal of Hellenic Studies, 109, $1-15$.

Dodds, E. R. (Ed.). (1966). Plato: Gorgias. Oxford: Clarendon Press.

Eucken, C. (2003). Die Doppeldeutigkeit des platonischen Menexenos. Hyperboreus, 9(1), 44-55.

Giannantoni, G. (Ed.). (1990). Socratis et Socraticorum reliquiae (Vols. I-IV). Napoli: Bibliopolis.

Heitsch, E. (2009). Thukydides, Aspasia und Platons Menexenos. Philologus, 153(2), 229-236.

Henderson, M. M. (1975). Plato's Menexenus and the distortion of history. Acta Classica, 18, 25-46.

Huby, P. M. (1957). The Menexenus reconsidered. Phronesis, 2(2), 104-114.

Kahn, C. H. (1963). Plato's funeral oration. The motive of the Menexenus. Classical Philology, 58, 220-234.

Kennedy, G. (1963). The Art of Persuasion in Greece. Princeton: University Press.

Labriola, I. (1980). Tucidide e Platone sulla democrazia ateniese. Quaderni di Storia, 6, 207-229.

Labriola, I. (2010). Il laboratorio di Aspasia. Invigilata Lucernis, 32, 61-73.

Lattanzi, G. (1953). Il significato e l'autenticità del Menesseno. Parola del Passato, 8, 303-306.

Loewenclau, I. v. (1961). Der platonische Menexenos. Stuttgart: Kohlhammer.

Méridier, L. (Ed.). (1964 ${ }^{4}, 1931^{1}$ ). Platon. CEuvres complètes (Vol. V/1). Paris: Les Belles Lettres.

Moggi, M. (1968). La tradizione sulle guerre persiane in Platone. Studi Classici e Orientali, 17, 213-226.

Monoson, S. S. (1998). Remembering Pericles: the political and theoretical import of Plato's Menexenus. Political Theory, 26(4), 489-513.

Nannini, S. (2014). Il «Menesseno» di Platone? Lexis, 32, 248-277.

Oppenheimer, K. (1933). Zwei attische Epitaphien. Berlin: Ebering.

Pappas, N., \& Zelcer, M. (2015). Politics and Philosophy in Plato's Menexenus. Education and Rhetoric, Myth and History. London - New York: Routledge.

Pohlenz, M. (1913). Aus Platos Werdezeit. Berlin: Weidmannsche Buchhandlung.

Ritter, C. (1910). Platon (Vol. I). München: Beck.

Salkever, S. G. (1993). Socrates' aspasian oration: the play of philosophy and politics in Plato's Menexenus. American Political Science Review, 87, 133-143.

Schleiermacher, F. (Ed.). (1861³, 1826², 1809¹). Platons Werke (Vol. II/3). Berlin: Reimer.

Scholl, N. (1959). Der platonische Menexenos. Roma: Storia e Letteratura.

Taylor, A. E. $\left(1960^{7}, 1926^{1}\right)$. Plato. The Man and His Work. London: Routledge. 
Trivigno, F. V. (2009). The rhetoric of parody in Plato's Menexenus. Philosophy and Rhetoric, 42(1), 29-58.

Tsitsiridis, S. (1998). Platons Menexenos. Stuttgart - Leipzig: Teubner.

Tulli, M. (2003). L'Atene di Aspasia: tradizione del racconto e ricerca dell'ideale nel Menesseno di Platone. In A. Casanova, \& P. Desideri (Eds.), Evento, racconto, scrittura nell'antichità classica (Vol. 1; pp. 91-106). Firenze: Dipartimento Giorgio Pasquali.

Wendland, P. (1890). Die Tendenz des platonischen Menexenus. Hermes, 25, 171-195.

Wilamowitz, U. v. (1920). Platon (Vol. II). Berlin: Weidmannsche Buchhandlung.

Ziolkowski, J. E. (1981). Thucydides and the Tradition of Funeral Speeches at Athens. New York: Arno Press.

Dr. Tito Storti / tito.storti@virgilio.it

Department of Classical Philology and Italian Studies FICLIT

Alma Mater Studiorum - University of Bologna

Via Zamboni 32, I-40126 Bologna, Italy 
